\section{Dramatic improvement of tardive dyskinesia movements by inline skating}

苗

Figure 1 Spine and wrist acceleration during gait and inline skating of the patient and her sister

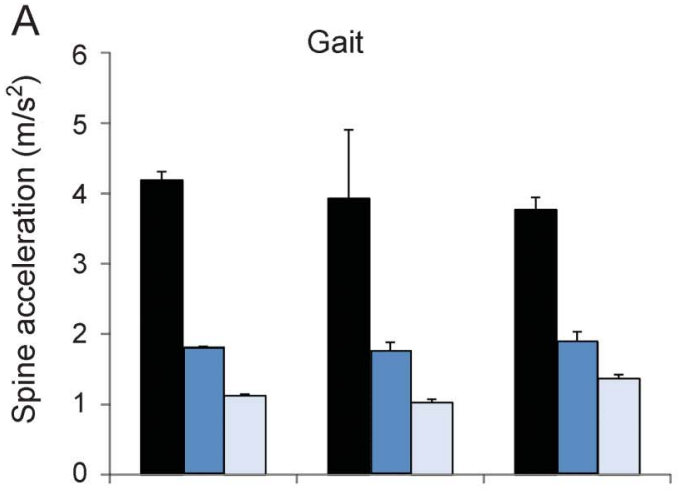

B

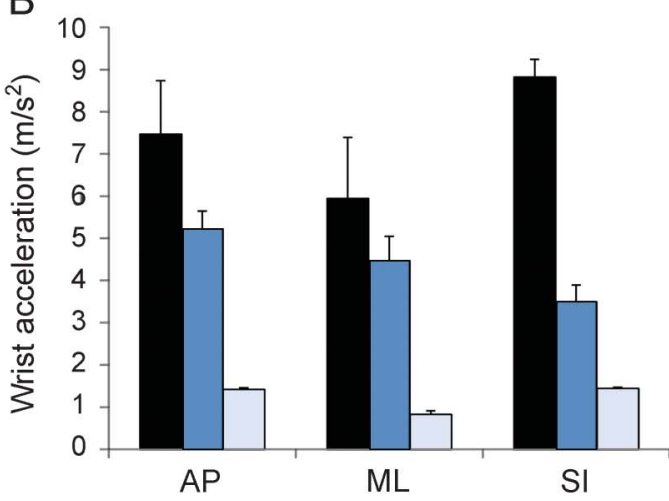

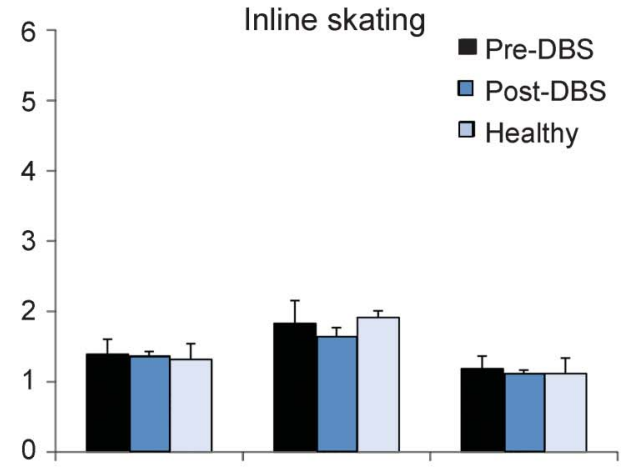

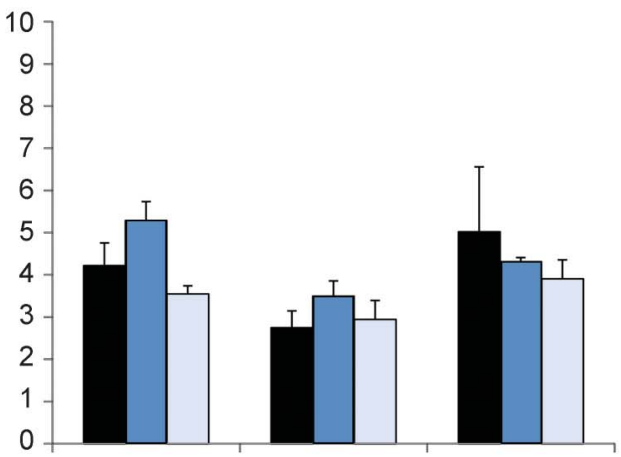

ML

SI

In gait analysis (A), the patient showed higher average acceleration for spine (upper trunk) and wrist compared to her healthy twin sister, even after deep brain stimulation (DBS). In inline skating (B), the values for the patient were similar to her healthy sister independent of DBS. AP = anteroposterior; $\mathrm{ML}=$ mediolateral; $\mathrm{SI}=$ superoinferior.

Supplemental data at Neurology.org
A 25-year-old woman with severe tardive dyskinesia (TD) due to neuroleptics had substantial improvement of movements while inline skating (video at Neurology.org). She received pallidal deep brain stimulation (DBS), and gait and inline skating were assessed before and after DBS; her twin sister served as a control (figures 1 and 2). Possible explanations for her improvement include (1) balance stability required by inline skating provides external cues that are less prominent during gait ${ }^{1}$; and (2) dystonia consistently responds to geste antagoniste. ${ }^{2}$ Since TD has variable response to treatments, we propose research into alleviating factors in TD that may advance treatment and rehabilitation in this incapacitating disorder.

Sara Carvalho Barbosa Casagrande, MD, Rubens Gisbert Cury, MD, PhD,

Andrea Cristina de Lima-Pardini, PhD, Daniel Boari Coelho, Carolina de Oliveira Souza, PhD,

Maria Gabriela dos Santos Ghilardi, MD, Laura Silveira-Moriyama, MD, PhD, Luis Augusto Teixeira, PhD,

Egberto Reis Barbosa, MD, PhD, Erich Talamoni Fonoff, MD, PhD

From the Hospital das Clínicas of the University of São Paulo (S.C.B.C., R.G.C., C.d.O.S., M.G.d.S.G., L.S.-M., E.R.B., E.T.F.); the University of São Paulo (A.C.d.L.-P., D.B.C., L.A.T.); and Universidade Nove de Julho (L.S.-M.), Uninove, São Paulo, Brazil.

Author contributions: S.C.B.C.: study concept, design, acquisition and interpretation of data, figure and video editing, literature search, writing of manuscript. R.G.C.: study concept, critical revision. A.C.d.L.-P.: acquisition of data, interpretation of data, critical revision, literature search. D.B.C.: acquisition of data, interpretation of data, figure and video editing. C.d.O.S.: study design, critical revision. M.G.d.S.G.: study design, critical revision. L.S.-M.: critical revision, literature search, writing of 

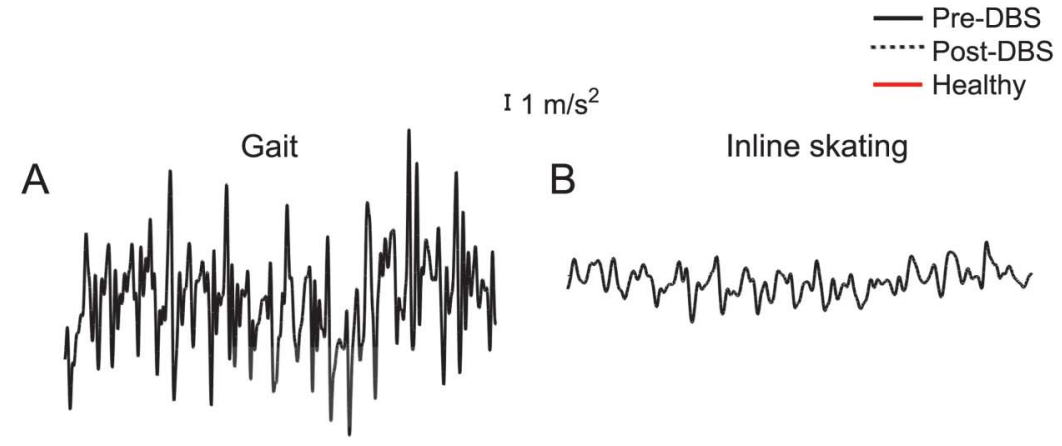

$\frac{1}{<}$
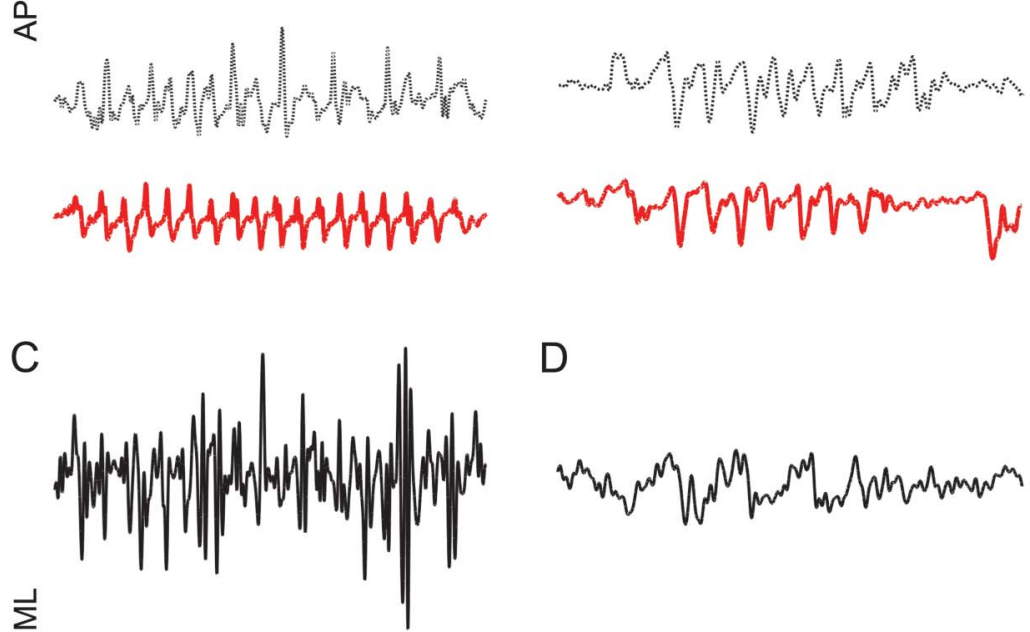

D
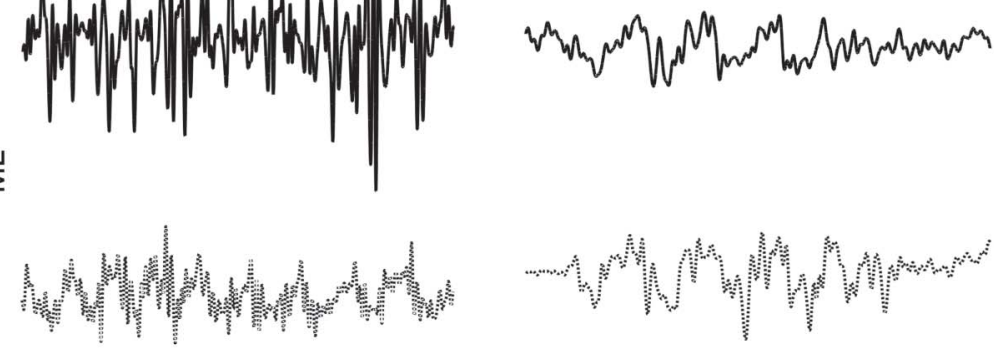

....
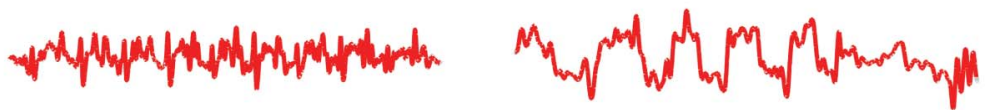

$\mathrm{E}$

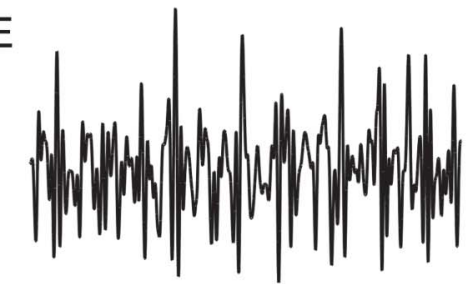

$\mathrm{F}$

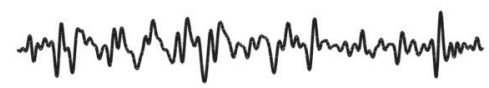

$\bar{\omega}$

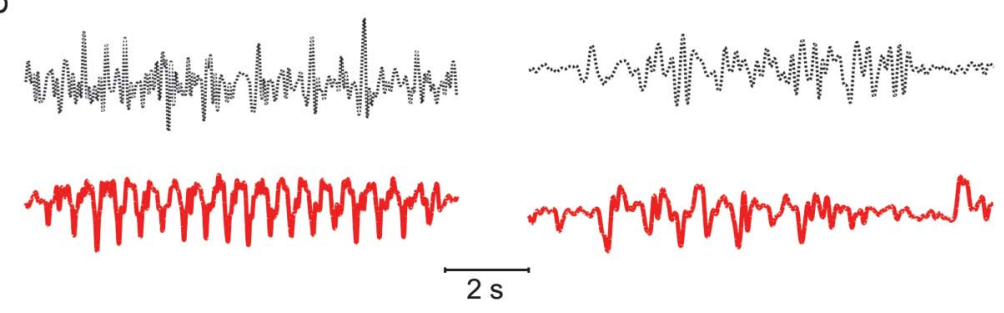

Individual trials show representative spine acceleration profiles in the performance of gait (left panels) and inline skating (right panels), comparing the signals from the patient before and after deep brain stimulation (DBS) in reference to her healthy twin sister. $\mathrm{AP}=$ anteroposterior $(\mathrm{A}, \mathrm{B}) ; \mathrm{ML}=$ mediolateral $(\mathrm{C}, \mathrm{D}) ; \mathrm{SI}=$ superoinferior $(\mathrm{E}, \mathrm{F})$.

manuscript. L.A.T.: critical revision, analysis and interpretation of data. E.R.B.: critical revision of the manuscript for important intellectual content, study supervision. E.T.F.: study concept, critical revision of the manuscript for important intellectual content, study supervision.

Study funding: No targeted funding reported. 
Disclosure: The authors report no disclosures relevant to the manuscript. Go to Neurology.org for full disclosures.

Correspondence to Dr. Casagrande: drasaracasagrande@gmail.com

1. Snijders AH, Bloem BR. Cycling for freezing of gait. N Engl J Med 2010;362:e46.

2. Patel N, Jankovic J, Hallett M. Sensory aspects of movement disorders. Lancet Neurol 2014;13:100-112.

\section{Discover Altmetrics}

See real-time downloads and online activity for articles!

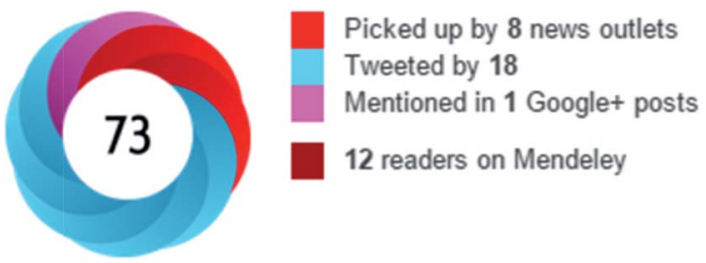

See more details

Authors and readers alike can view real-time data on articles including downloads and online activity across multiple sources. Click on the "Article Metrics" link in the right column of an article for details. To learn more about article metrics visit http://www.neurology.org/site/misc/article_usage.xhtml.

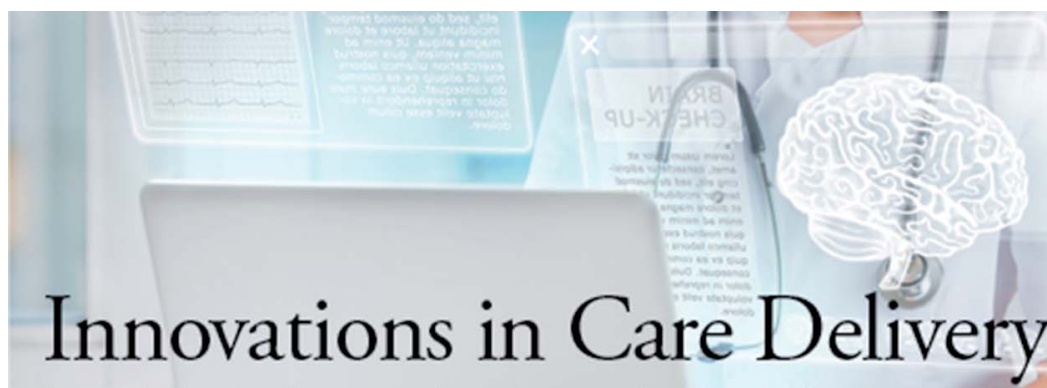

A curated collection featuring advances in neurologic care

NEW!

\section{Innovations in Care Delivery - A curated collection featuring advances in neurologic care}

This Neurology ${ }^{\circledR}$ special interest website provides a forum to explore new care models from multiple disciplines, access to sources on health care innovation, and expert opinions on current research from Neurology journals. Curated by Brian C. Callaghan, MD, and Kevin A. Kerber, MD.

Stay ahead of the curve at Neurology.org/innovations. 


\section{Neurology}

Dramatic improvement of tardive dyskinesia movements by inline skating

Sara Carvalho Barbosa Casagrande, Rubens Gisbert Cury, Andrea Cristina de Lima-Pardini, et al.

Neurology 2017;89;211-213

DOI 10.1212/WNL.0000000000004092

This information is current as of July 10, 2017

\section{Updated Information \&} Services

Supplementary Material

\section{References}

Subspecialty Collections

Permissions \& Licensing

Reprints including high resolution figures, can be found at: http://n.neurology.org/content/89/2/211.full

Supplementary material can be found at: http://n.neurology.org/content/suppl/2017/07/10/WNL.0000000000004 092.DC1

This article cites 2 articles, 0 of which you can access for free at: http://n.neurology.org/content/89/2/211.full\#ref-list-1

This article, along with others on similar topics, appears in the following collection(s):

Gait disorders/ataxia

http://n.neurology.org/cgi/collection/gait_disorders_ataxia Motor Control

http://n.neurology.org/cgi/collection/motor_control

Surgery/Stimulation

http://n.neurology.org/cgi/collection/surgery-stimulation

Information about reproducing this article in parts (figures,tables) or in its entirety can be found online at:

http://www.neurology.org/about/about_the_journal\#permissions

Information about ordering reprints can be found online:

http://n.neurology.org/subscribers/advertise

Neurology ${ }^{\circledR}$ is the official journal of the American Academy of Neurology. Published continuously since 1951, it is now a weekly with 48 issues per year. Copyright () 2017 American Academy of Neurology. All rights reserved. Print ISSN: 0028-3878. Online ISSN: 1526-632X.

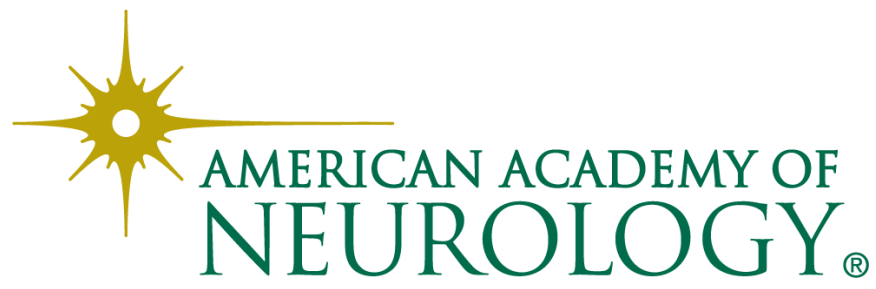

